\title{
EVALUASI COACHING MENGGUNAKAN KERANGKA MODEL KIRKPATRICK DALAM PELATIHAN KEPEMIMPINAN ADMINISTRATOR DAN PENGAWAS DI PUSAT PENGEMBANGAN SUMBER DAYA MANUSIA APARATUR, KEMENTERIAN ENERGI DAN SUMBER DAYA MINERAL
}

\author{
Makmun Abdullah \\ Pusat Pengembangan Sumber Daya Manusia Aparatur \\ makmun.abdullah@esdm.go.id
}

\begin{abstract}
ABSTRAK
Coaching telah menjadi bagian integral dari penyelenggaraan pelatihan kepemimpinan untuk meningkatkan efektivitas pembelajaran dan menimbulkan kesadaran diri serta perubahan individu sehingga siap menghadapi tantangan organisasi. Pelaksanaan coaching seharusnya mampu menunjang efektivitas pelatihan sehingga mampu mencapai tujuan pembelajaran yang diinginkan dalam kurikulum. Meskipun diakui penting, sampai saat ini evaluasi pelaksanaan coaching pada pelatihan kepemimpinan masih belum dilakukan secara komprehensif. Penelitian ini diharapkan mampu menjawab pertanyaan tentang sejauh mana tingkat efektivitas coaching yang telah dilaksanakan oleh Coach (Widyaiswara) terhadap para peserta Pelatihan Kepemimpinan di PPSDM Aparatur selama ini. Evaluasi coaching ini menggunakan kerangka Model evaluasi empat level Kirkpatrick sebagai basis yang dilengkapi dengan pendekatan multidimensi dengan mempertimbangkan semua aspek yang berpengaruh. Penelitian ini menggunakan pendekatan kuantitatif deskriptif melalui studi literatur dan penyebaran kuesioner kepada responden, yaitu alumni dan coach pada Pelatihan Kepemimpinan Administrator dan Pengawas (Diklatpim Tingkat III dan IV) di KESDM Tahun 2018. Hasil penelitian menunjukkan bahwa para peserta pelatihan merasa puas dan telah merasakan manfaat serta dampak pembimbingan melalui coaching yang telah dilakukan selama pelatihan.
\end{abstract}

\section{Kata Kunci: Pelatihan Kepemimpinan, Coaching, Evaluasi, Kirkpatrick}

\begin{abstract}
Coaching has become an integral part of organizing leadership training to improve learning effectiveness and generate self-awareness and individual change so they are ready to face organizational challenges. Coaching should be able to support the effectiveness of training so that it can achieve the desired learning goals in the curriculum. Although recognized as important, until now the evaluation of the implementation of coaching in leadership training has not been carried out comprehensively. This research is expected to answer questions about the extent of the the effectiveness of coaching that has been carried out by Coach (Widyaiswara) to the participants of the Leadership Training at PPSDM Apparatus so far. Coaching evaluation will use the Kirkpatrick's four levels of evaluation model framework as a basis that is complemented by a multidimensional approach that considers all aspects that will influence. This research uses a descriptive quantitative approach through the study of literature and the distribution of questionnaires to respondents, namely alumni and coaches in the Leadership Training of Administrator and Supervisor (Diklatpim Level III and IV) in the Ministry of Energy and Mineral Resources in 2018. The results showed that the training participants were satisfied and had felt the benefits and impacts of learning through coaching that has been done during the training.
\end{abstract}

\section{Keywords: Leadership Training, Coaching, Evaluation, Kirkpatrick}

\section{PENDAHULUAN}

Coaching merupakan metode pengembangan kepemimpinan yang paling berkembang saat ini (Mccauley, 2008 dan Joyce E. Bono et al, 2009). Coaching kepemimpinan (Leadership Coaching) merupakan bagian integral dari strategi pengembangan kepemimpinan dalam organisasi yang paling banyak digunakan saat ini (Fillery et al, 2006; Underhill et al, 2008; White, 2010).
Coaching kepemimpinan digambarkan sebagai salah satu bentuk intervensi pengembangan yang memungkinkan individu dapat menyesuaikan diri secara cepat terhadap perubahan besar yang ada di lingkungan kerjanya dan sering digunakan dalam pengelolaan organisasi, terutama untuk meningkatkan pembelajaran, pengembangan diri, dan kinerja pegawai (Campone, 2015; Blackman, 2010; Grover, 2016). Coaching dalam hal ini 
dilakukan untuk memfasilitasi pembelajaran individu dan perubahan perilaku, jadi lebih berfokus pada bagaimana menghadapi situasi tertentu daripada menunjukkan tindakan apa harus diambil oleh coachee (Agarwal, 2009). Coaching juga lebih ditekankan pada umpan balik yang konstruktif, pengembangan untuk meningkatkan kinerja, dan kemampuan untuk mengatasi masalah yang dihadapi (Ellinger et al, 2003). Melalui penerapan coaching yang benar diharapkan dapat membantu peserta pelatihan untuk meningkatkan kinerja individu dengan meningkatkan kesadaran diri dan mengembangkan perilaku baru (Kombarakaran et al, 2008). Meskipun diakui penting, evaluasi terhadap penyelenggaraan coaching pada pelatihan kepemimpinan sampai saat ini masih jarang dilakukan (Feldman \& Lankau, 2005; MacKie, 2007). Hasil survei McDermott \& Levenson (2007) menunjukkan, hanya sepertiga penyelenggaraan coaching yang dievaluasi.

Coaching merupakan salah satu metode pembimbingan yang diterapkan dalam pelatihan kepemimpinan selain mentoring. Pembimbingan pembelajaran aksi perubahan melalui coaching ini dilakukan baik di tempat pelatihan maupun di tempat kerja pada saat para peserta pelatihan merancang dan mengimplementasikan aksi perubahan kinerja pelayanan publik di tempat kerjanya. Hal ini sesuai dengan Keputusan Kepala Lembaga Administrasi Negara Nomor 1008/K.1/PDP.07/ 2019 dan 1006/K.1/PDP.07/2019 Tentang Kurikulum PKA dan PKP. Coach sendiri sesuai dengan pedoman penyelenggaraan PKA dan PKP didefinisikan sebagai Widyaiswara atau pegawai lainnya yang memiliki kompetensi dalam menggali potensi Peserta untuk melaksanakan pembimbingan pembelajaran Aksi Perubahan dan mendapatkan penugasan dari pimpinan lembaga penyelenggara pelatihan. Persyaratan menjadi coach disebutkan meliputi, telah memiliki surat keterangan pelatihan penyamaan persepsi strategi pembimbingan, integritas, komitmen, penguasaan materi, strategi pembelajaran, dan jadwal pelatihan. Sampai saat ini memang belum ada pedoman coaching yang telah dikeluarkan oleh Lembaga Administrasi Negara (LAN) dalam pelatihan kepemimpinan, sehingga belum ada acuan baku dalam pelaksanaannya.

Fakta yang ada bahwa penyelenggaraan pelatihan yang memakan waktu begitu lama dan biaya yang besar untuk membekali para peserta dengan aspek pengetahuan, keterampilan, dan perilaku kepemimpinan menunjukkan bahwa akan masuk akal apabila kemudian dilakukan penilaian terhadap efektivitas pelaksanaannya. Perlu pemahaman yang sama terhadap pentingnya evaluasi terhadap penyelenggaraan coaching pada pelatihan kepemimpinan, terutama untuk menentukan apa yang harus diukur dan bagaimana melakukannya.

Pelaksanaan coaching pada penyelenggaraan pelatihan kepemimpinan di PPSDMA selama ini tentu saja masih banyak mengandung kelemahan. Oleh karena itu, wajar apabila kemudian muncul beberapa pertanyaan, misalnya: sejauh mana kualitas proses coaching yang telah dilakukan oleh Widyaiswara PPSDSM Aparatur selama ini? Apakah proses coaching yang dilakukan telah sesuai dengan kebutuhan peserta? Apakah peserta merasa puas dengan proses coaching yang telah dilakukan? Apakah peserta pelatihan telah berhasil mencapai tujuan dan sasaran yang diinginkan dalam pelaksanaan coaching? Sejauh mana coaching telah berdampak terhadap peserta pelatihan? Termasuk hal-hal yang masih perlu diperbaiki dalam proses coaching. Hasil evaluasi paska-pelatihan juga menunjukkan masih adanya perbedaan standar dalam pembimbingan (coaching) yang dilakukan oleh para coach pada saat merancang proyek perubahan (PPSDM Aparatur, 2018). Seluruh pertanyaan tersebut hanya dapat dijawab apabila telah dilakukan evaluasi terhadap proses coaching pada pelatihan kepemimpinan tersebut. Hasil evaluasi juga akan memberikan informasi untuk perbaikan pelaksanaan coaching ke depannya agar semakin meningkat kualitasnya.

Berdasarkan hasil identifikasi permasalahan di atas, maka penelitian ini dimaksudkan untuk mengevaluasi proses coaching dan pencapaian tujuan pembelajaran (pembimbingan) yang telah dilakukan melalui coaching sehingga pada akhirnya akan diketahui sejauh mana tingkat efektivitas pelaksanaan coaching yang telah dilaksanakan oleh Coach (Widyaiswara) di PPSDMA terhadap para peserta pelatihan kepemimpinan.

\section{TINJAUAN TEORITIS DAN PENELITIAN SEBELUMNYA \\ 1. Coaching dalam Program Pengembangan Kepemimpinan \\ Coaching sebagai salah satu metode} pengembangan dalam pelatihan kepemimpinan memang telah banyak diteliti. Hasil penelusuran menggunakan Google Cendekia menunjukkan bahwa dalam satu dekade ini, tulisan terkait Leadership Coaching meningkat hampir dua kali lipat dari sejumlah 12.800 tulisan pada tahun 2010, menjadi 22.400 pada tahun 2019 yang sebagian 
besar berbentuk jurnal dan buku. Demikian pula pada saat menelusuri terkait Leadership Coaching Evaluation, tahun 2019 saja terdapat hampir 19.500 tulisan. Meskipun demikian, penelitian tentang evaluasi coaching dalam suatu program pelatihan kepemimpinan saat ini masih sangat terbatas. Hal ini tentu saja menimbulkan banyak pertanyaan terkait efektivitas coaching dalam menciptakan figur seorang pemimpin. Schmidt \& Bjork (1992) menyatakan bahwa program pelatihan kepemimpinan yang berdiri sendiri, tidak akan mengarah kepada kinerja yang optimal. Hal ini dikarenakan pelatihan tersebut tidak secara eksplisit memberikan keterampilan meta-kognitif kepada peserta, namun hanya fokus kepada penguasaan keterampilan baru (Carver \& Scheier, 1998), sementara coaching membantu para peserta pelatihan menjadi lebih reflektif dan analitik sehingga memiliki kemampuan untuk mengidentifikasi bidang-bidang tertentu yang perlu ditingkatkan.

Sebagian besar program pengembangan kepemimpinan yang ada saat ini, telah mengintegrasikan coaching sebagai bagian yang tidak terpisahkan (Nyman et al, 2002; Mackenzie, 2007; Koonce, 2010; Grosseck, 2014; Schalk \& Landeta, 2017). Coaching adalah tentang membuka potensi orang untuk memaksimalkan kemampuan mereka, membantu mereka untuk belajar, bukan sekedar mengajari, karena tujuan utama coaching adalah untuk mendukung pengembangan peserta didik (Mary Devine, 2013). Inti dari pendekatan coaching ini adalah fasilitasi pembelajaran dengan cara mendengarkan (active listening) dan bertanya serta memberikan tantangan dan dukungan secara tepat. Pengertian coaching dalam pengembangan kepemimpinan (leadership coaching), diartikan sebagai hubungan antara coach dengan coachee untuk memfasilitasi agar mampu menjadi pemimpin yang lebih efektif (Killburg, 1996; Pfeiffer, 2005; Joyce \& Peterson, 2009; White, 2010). Coach dan coachee berkolaborasi untuk menilai dan memahami coachee serta kebutuhan pengembangannya, menghadapi kendala yang timbul sambil mengeksplorasi kemungkinan alternatif baru, dan memastikan akuntabilitas serta dukungan untuk mencapai tujuan serta pengembangan yang berkelanjutan (Ting \& Hart, 2004 dalam Ting \& Scisco, 2006). Coaching telah berkembang menjadi metode yang ampuh untuk mendorong perubahan individu dan pembelajaran (Mary Devine, 2013).

Berbagai hasil kajian literatur menekankan peran penting seorang coach. Salah satu peran kunci yang harus diperankan oleh seorang coach adalah menjadi fasilitator pengembangan secara profesional. Dean (2002) menyarankan agar Coach memiliki pengetahuan dasar dan keahlian yang dibutuhkan untuk mencapai tujuan dan sasaran yang diinginkan sehingga kualitas coach akan sangat berpengaruh terhadap keberhasilan peserta pelatihan kepemimpinan dalam pembelajaran. Dalam peran ini, coach membantu coachee untuk mengorganisasikan pemikiran agar lebih obyektif, dan mengembangkan kapasitas yang lebih besar sehingga mampu mengelola perubahan. Karena itu coach yang efektif harus mampu memahami permasalahan organisasi saat ini, memotivasi individu, dampak emosi dan gaya interpersonal pada kepemimpinan manajerial. Coach juga perlu memahami masalah kepemimpinan dan manajemen dari sudut pandang multisistem dan realitas politik dan ekonomi dalam organisasi dan lingkungannya yang kompetitif. Mereka juga membutuhkan kesadaran dan pengetahuan untuk menjaga kerahasiaan yang
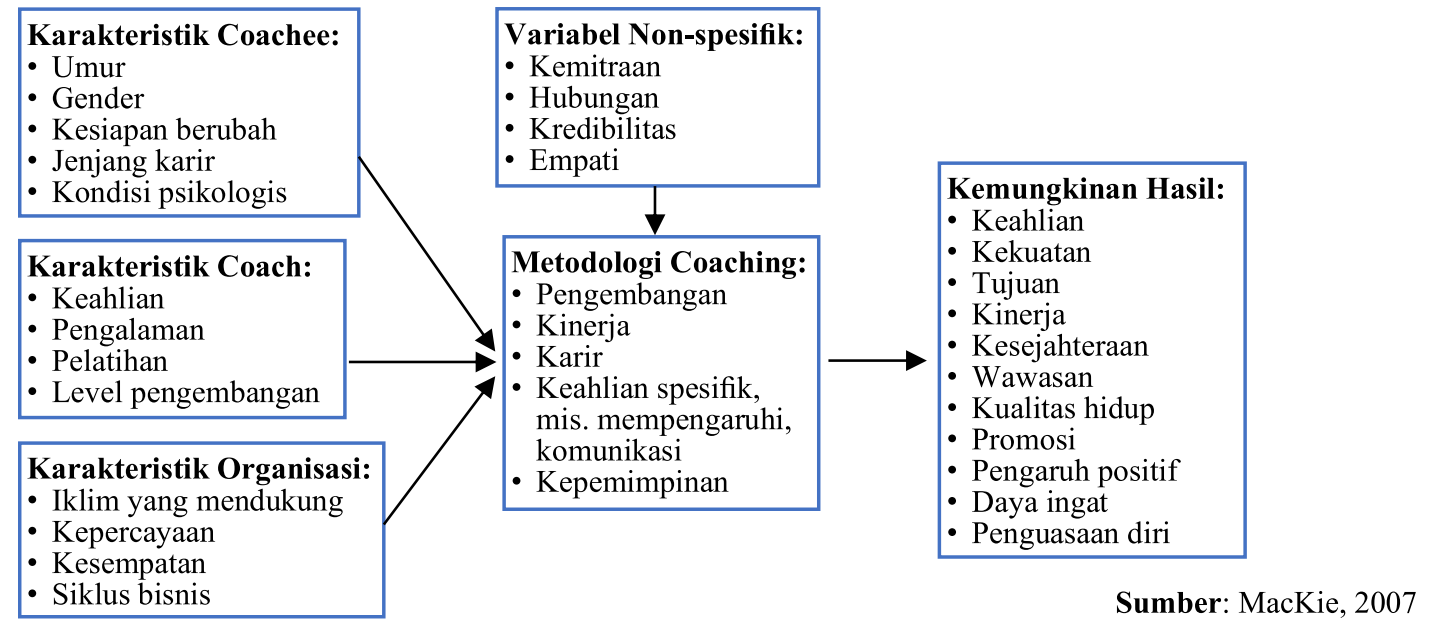

Gambar 1. Pendekatan Komprehensif Evaluasi Coaching Kepemimpinan 
tepat serta batas-batas peran dan perilaku yang tepat antara coach, eksekutif, dan bawahannya (Hayes, 1997; Levinson, 1996; The Executive Coaching Forum, 2015).

Masing-masing pihak (coach dan coachee) memiliki tanggung jawab untuk efektivitas proses coaching yang diselenggarakan. Keberhasilan coaching sangat tergantung pada sejumlah variabel, di antaranya pengalaman, keterampilan interpersonal, motivasi, dan komitmen (MacKie, 2007). Beberapa variabel lain yang juga harus dipertimbangkan adalah karakteristik coach, coachee, dan dukungan organisasi (Gambar 1).

\section{Coaching pada Pelatihan Kepemimpinan Administrator dan Pengawas (PKA dan PKP)}

PPSDM Aparatur telah menyelenggarakan Pelatihan Kepemimpinan (Diklatpim Tingkat III dan IV) sejak tahun 2017 yang pesertanya berasal dari internal Kementerian ESDM sendiri. Kompetensi yang ingin dibangun pada penyelenggaraan Program Pelatihan Kepemimpinan Administrator (PKA) dan Pengawas (PKP) sesuai dengan Keputusan Kepala Lembaga Administrasi Negara Nomor 1008/K.1/PDP.07/2019 Tentang Kurikulum PKA dan Keputusan Kepala Lembaga Administrasi Negara Nomor 1006/K.1/PDP.07/ 2019 Tentang Kurikulum PKP. Kompetensi yang dibangun dalam PKA/PKP adalah kompetensi manajerial jabatan administrator/pengawas dan kompetensi pemerintahan sebagai administrator/pengawas. Melalui penguasaan kompetensi tersebut secara terintegrasi, PKA dan PKP mampu mewujudkan sosok kepemimpinan berkinerja yang diindikasikan dengan karakter dan sikap perilaku, serta kemampuan melakukan inovasi, kolaborasi, dan mengoptimalkan seluruh potensi sumber daya internal dan eksternal dalam me- ningkatkan kinerja organisasi dan administrasi pemerintahan serta pembangunan di unit kerjanya.

Pelatihan dilaksanakan secara klasikal dan nonklasikal dengan jumlah Jam Pelajaran on campus $257 \mathrm{JP}$ (31 hari) pada PKA dan untuk PKP adalah 290 JP (36 hari). Pembelajaran dilakukan melalui pembelajaran di kelas melalui tatap muka, belajar mandiri melalui e-learning, dan pembimbingan (coaching dan mentoring), baik di tempat pelatihan maupun di tempat kerja. Kurikulum pembelajaran pelatihan kepemimpinan dilakukan melalui 4 (empat) agenda pembelajaran yang kemudian dijabarkan ke dalam beberapa mata pelatihan yang akan menghasilkan produk pembelajaran (Gambar 1 dan 2). Pembimbingan selama merancang dan implementasi aksi perubahan yang dilakukan selama on dan off-campus dilakukan menggunakan metode coaching dan mentoring. Coaching selama ini dilakukan oleh para Widyaiswara yang ditunjuk, sedangkan mentoring oleh atasan peserta pelatihan kepemimpinan yang bersangkutan. Coaching dilakukan secara formal (face to face atau coaching group) dan informal (telpon, email, dan media sosial) selama on dan off campus.

\section{Evaluasi Pelaksanaan Coaching dengan Pendekatan Kirkpatrick}

Coaching dalam pelatihan kepemimpinan (diklat kepemimpinan) berbeda dari metode pendekatan lainnya dan memiliki tantangan khusus dalam evaluasinya (Ely, et al., 2010). Hal ini dikarenakan coaching seringkali dilakukan dalam konteks hubungan individu (one on one relationship) dan prosesnya sangat bervariasi dari orang ke orang. Evaluasi coaching sebaiknya dilakukan dalam kerangka evaluasi yang terpadu. Para peneliti dan praktisi umumnya mengklasifikasikan evaluasinya menjadi dua jenis, yaitu

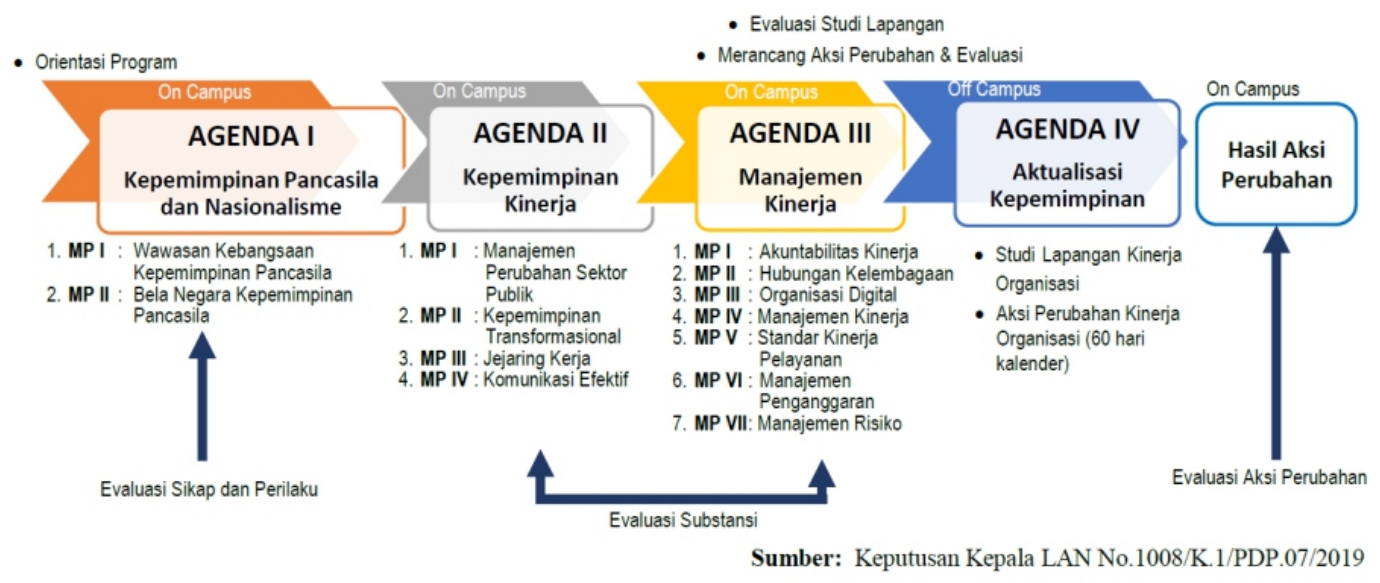

Gambar 1. Tahapan Pembelajaran dalam Pelatihan Kepemimpinan Administrator 


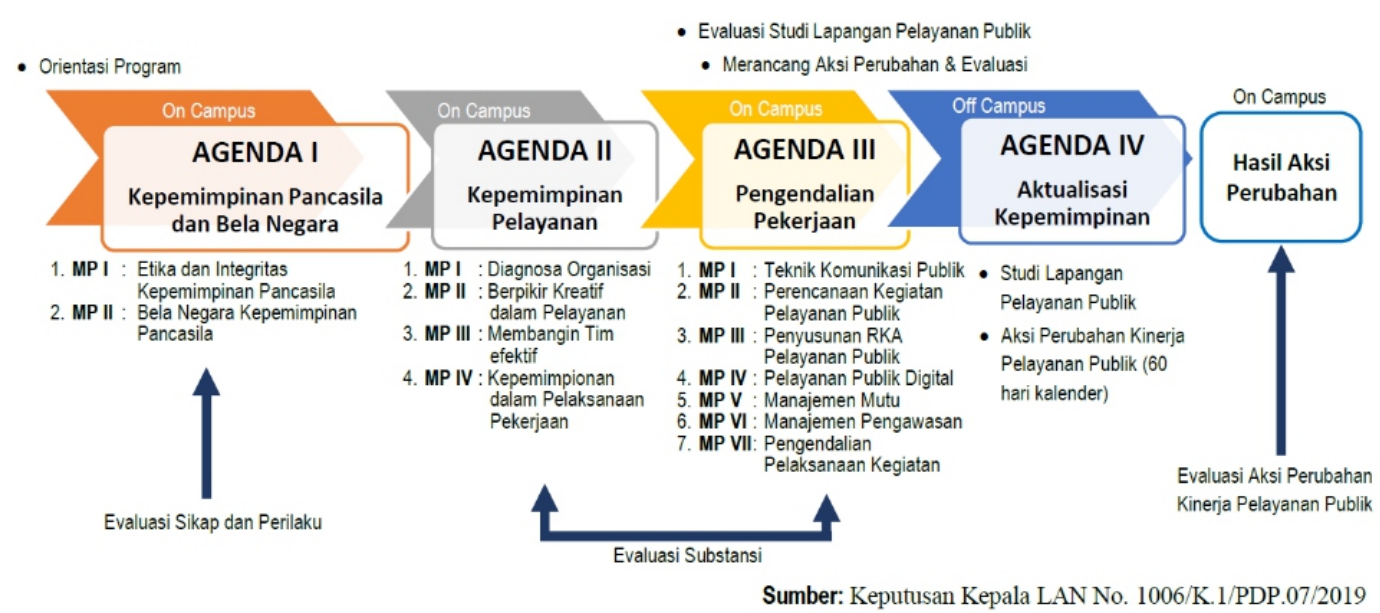

Gambar 2. Tahapan Pembelajaran dalam Pelatihan Kepemimpinan Pengawas

sumatif dan formatif (Biggs \& Tang, 2007). Pemahaman terhadap tujuan evaluasi atas penyelenggaraan coaching sangat penting untuk menentukan apa yang harus diukur. Faktor-faktor yang berpengaruh, seperti sumber daya yang tersedia (waktu, sarana, dan aspek teknis lainnya), urgensi, dan proses serta dampak coaching akan menentukan cara untuk mengukur keefektifannya.

Model evaluasi yang akan digunakan dalam evaluasi coaching ini adalah Model yang dikenalkan oleh Donald L. Kirkpatrick sejak tahun 1959, yang kemudian diperbarui pada 1975 dan 1993 ketika dia mempublikasikan karya terbaiknya "Evaluating training Programs.". Selanjutnya model evaluasi pelatihan ini terus dikembangkan oleh putranya, James D. Kirkpatrick dan istrinya Wendy Kaiser Kirkpatrick. Evaluasi Empat level ini meliputi reaksi, pembelajaran, perilaku, dan hasil (reaction, learning, behaviour, dan results) yang selama empat dekade terakhir telah teruji untuk mengevaluasi program pelatihan dan pengembangan sumber daya manusia.

Menurut Goldstein \& Ford (2002), Model Kirkpatrick yang secara luas telah digunakan di kalangan praktisi pelatihan memberikan fondasi yang kuat untuk mengidentifikasi kriteria evaluasi coaching kepemimpinan yang relevan. Meskipun demikian terdapat kritik terhadap model Kirkpatrick terkait "transfer", yaitu kegagalan se-

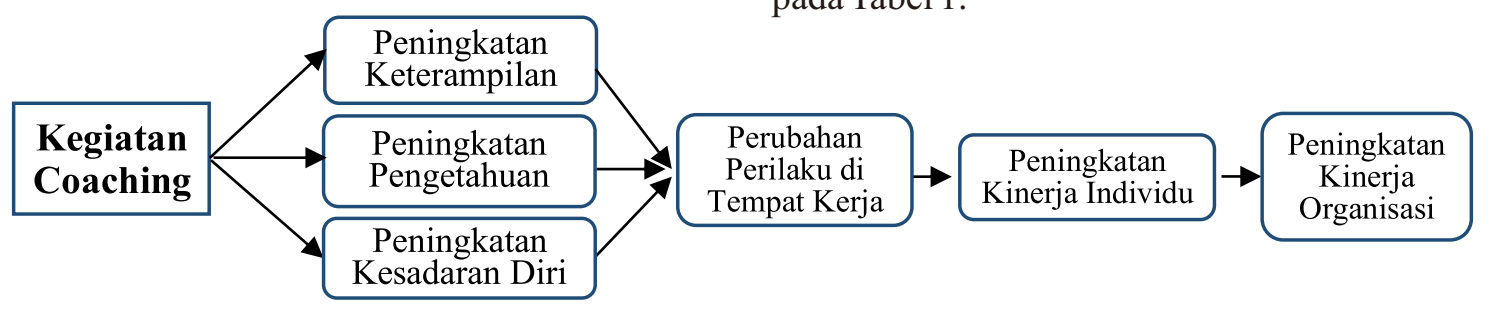

Gambar 3. Alur Pikir Evaluasi Coaching Menggunakan Model Kirkpatrick bagian besar pelatihan memberikan dampak terhadap perubahan perilaku di tempat kerja (Baldwin $\&$ Ford, 1988). Model empat level dianggap kurang mempertimbangkan pengaruh individu atau kontekstual dalam evaluasi pelatihan, meliputi karakteristik organisasi dan individu, desain pembelajaran, dan lingkungan kerja yang dapat memengaruhi efektivitas pelatihan sebelum, selama, atau setelah pelatihan (Salas, Tannenbaum, \& Mathieu, 1995; Bates, 2004; MacKie, 2007). Bates menyarankan untuk meningkatkan model dan aplikasi dalam evaluasi coaching agar memberi manfaat yang lebih berarti kepada klien dan pemangku kepentingan. Kerangka kerja Kirkpatrick perlu dilengkapi dengan pendekatan multidimensi dalam evaluasi yang dilakukan. Kerangka evaluasi ini akan memberikan mekanisme untuk menjabarkan kriteria hasil yang relevan sebagai bagian dari evaluasi sumatif (Gambar 3).

Perubahan individu dan kinerja organisasi akan dinilai, meskipun sulit untuk menghubungkan antara perubahan yang terjadi dengan hasil evaluasi coaching. Model evaluasi membutuhkan kejelasan pada tingkat mana akan dilakukan, apakah kepuasan setelah kegiatan coaching, tingkat pengetahuan, keterampilan atau kesadaran, ataukah pada tingkat perubahan perilaku atau kinerja organisasi (MacKie, 2007). Penerapan model kerangka evaluasi coaching ini dapat dilihat pada Tabel 1. 
Tabel 1. Penerapan Kerangka Evaluasi Sumatif Kirkpatrick

\begin{tabular}{|c|c|}
\hline $\begin{array}{c}\text { LEVEL } \\
\text { EVALUASI }\end{array}$ & DESKRIPSI DAN ARTI \\
\hline $\begin{array}{l}\text { Level Satu } \\
\text { (Reaksi): } \\
\text { Reaksi Coachee } \\
\text { Terhadap Program }\end{array}$ & $\begin{array}{l}\text { Mengukur reaksi coachee terhadap proses } \\
\text { coaching: } \\
\text { - Persepsi coachee terhadap efektivitas } \\
\text { coaching; } \\
\text { - Persepsi coachee terhadap coach (misal: } \\
\text { kompetensi); } \\
\text { - Kepuasan terhadap hubungan coach-coachee } \\
\text { (misal: kepercayaan) } \\
\text { - Kepuasan terhadap proses coaching (mis: } \\
\text { frekuensi pertemuan) }\end{array}$ \\
\hline $\begin{array}{l}\text { Level Dua } \\
\text { (Pembelajaran): } \\
\text { Tingkat kesadaran } \\
\text { dan pencapaian } \\
\text { keterampilan }\end{array}$ & $\begin{array}{l}\text { Mengukur pembelajaran dan perubahan dalam } \\
\text { pengetahuan atau keterampilan: } \\
\text { - Kesadaran diri; } \\
\text { - Fleksibilitas pengetahuan; } \\
\text { - Kemampuan menguasai situasi dan } \\
\text { mendapatkan hasil positif (self-efficacy); } \\
\text { - Sikap kerja (misal: kepuasan kerja, komitmen } \\
\text { organisasi). }\end{array}$ \\
\hline $\begin{array}{l}\text { Level Tiga: } \\
\text { Perubahan } \\
\text { Perilaku dan } \\
\text { Peralihan }\end{array}$ & $\begin{array}{l}\text { Mengukur penerapan keterampilan/ pengetahuan } \\
\text { baru dalam tugas pekerjaan tertentu: } \\
\text { - Perubahan dalam perilaku kepemimpinan klien } \\
\text { (misal: mengelola bawahan) } \\
\text { - Pencapaian coachee terhadap tujuan coaching }\end{array}$ \\
\hline $\begin{array}{l}\text { Level Empat: } \\
\text { Dampak Terhadap } \\
\text { Organisasi }\end{array}$ & $\begin{array}{l}\text { Mengukur dampak dan hasil pada organisasi: } \\
\text { - Kontrol terhadap staf (bawahan coachee). } \\
\text { - Jalur karir untuk mengisi posisi lebih tinggi; } \\
\text { - Perubahan yang dialami bawahan (misal: } \\
\text { kepuasan kerja dan kinerja); } \\
\text { - Peningkatan kepuasan kustomer; } \\
\text { - Laba atas investasi (RoI). }\end{array}$ \\
\hline
\end{tabular}

MODEL PERTANYAAN YANG AKAN DIAJUKAN

SUMBER DATA

- Seberapa puas coachee dan/ atau coach

- Apa yang disukai atau tidak disukai coachee tentang coaching?

- Perubahan apa yang ingin dilakukan Coachee?

- Bagaimana coachee merencanakan untuk menerapkan hasil dari coaching dalam kehidupan atau pekerjaan?

- Bagaimana coachee berpikir bahwa hasil pelatihan akan dapat mempengaruhi organisasi?

- Sejauh mana keterampilan atau pengetahuan baru ditunjukkan?

- Apa kesadaran atau wawasan baru yang muncul dari proses coaching?

- Sejauh mana coaching telah berdampak pada tingkat kemampuan coachee?

Bagaimana keterampilan atau cara berinteraksi yang baru telah digunakan dalam pekerjaan?

- Sampai sejauh mana perubahan perilaku berdampak pada pekerjaan sebagai hasil coaching?

- Observasi langsung

- Penilaian orang lain

- Penilaian formal (pre dan postassessment)

- Apa perbedaan yang telah dibuat coachee sebagai hasil coaching yang berdampak terhadap kinerja organisasi?

- Apa laba atas investasi $(R o I)$ atau perbandingan biaya/ manfaat yang terealisasi melalui coaching?
Penjelasan terhadap kerangka evaluasi berdasarkan empat level Kirkpatrick adalah sebagai berikut:

\section{a. Reaksi (reaction)}

Level reaksi akan difokuskan pada reaksi peserta pelatihan kepemimpinan terhadap program coaching. Aspek reaksi dalam konteks coaching kepemimpinan ini digunakan untuk menilai kepuasan coachee terhadap pengalaman coaching mereka menjadi persepsi terhadap efektivitas coaching (Ely, et al., 2010). Pertanyaan yang diajukan sebaiknya bersifat multidimensi sehingga dapat digunakan untuk menilai kepuasan coachee dari sisi yang berbeda terhadap coaching yang telah dilakukan. Tingkat kepuasan terhadap coach, kualitas hubungan antara coach-coachee, dan proses coaching sendiri merupakan hal yang sangat penting untuk diketahui (Fielden, 2005; Blackman A. C., 2007; O'Dell, 2011). Aspek reaksi ini akan memberikan umpan balik kepada coach dan organisasi terhadap
Sumber: MacKie (2007) dan Ely (2010) dengan penyesuaian

perbaikan coaching dan penugasan coach.

\section{b. Pembelajaran (Learning)}

Kirkpatrick level kedua ini mencoba memotret apa yang telah dipelajari peserta dalam coaching. Kreiger et al. (1993) menyatakan bahwa hasil belajar bersifat multi-dimensional karena aspek perubahan sikap seringkali terabaikan. Pembelajaran kognitif dalam konteks coaching kepemimpinan, meliputi kesadaran diri dan fleksibilitas kognitif (Bozer \& Joo, 2015; Federation, 1998). Fleksibilitas kognitif ini diidentifikasi oleh Zaccaro (1996) sebagai kemampuan pemimpin untuk menghadapi berbagai perubahan dan situasi yang komplek. Kemampuan ini merupakan hasil pembelajaran utama coaching untuk menumbuhkan fleksibilitas kognitif. Sedangkan perubahan afektif diartikan sebagai perubahan sikap dan motivasi yang relevan dengan tujuan coaching (Kraiger \& Ford, 1993). Perubahan ini akan berpengaruh terhadap perilaku dan kinerja selanjutnya. Dua hasil pembelajaran 
utama aspek afektif dalam coaching meliputi self-efficacy dan sikap kerja. Self-efficacy akan menangkap sejauh mana coachee yakin bahwa mereka akan berhasil menggunakan pengetahuan dan keterampilan yang dimilikinya (Bandura, 1991).

\section{c. Perilaku (Behavior)}

Taksonomi level ketiga Kirkpatrick adalah perilaku yang mengacu pada pengaruh coaching terhadap kepemimpinan atau pekerjaan. Perilaku kepemimpinan yang efektif menurut Yuki, (2012) meliputi, orientasi pada tugas (memastikan orang, peralatan, dan sumber daya lain digunakan secara efisien), perilaku hubungan (perilaku untuk meningkatkan keterampilan anggota tim dan hubungan kerja sama dalam unit), dan perilaku perubahan (peningkatan dan adaptasi terhadap inovasi). Terdapat perbedaan pendapat di antara para ahli terhadap perilaku kepemimpinan, sehingga penting untuk mengidentifikasi perilaku spesifik yang ditargetkan oleh penilaian dan mengevaluasi perubahan coachee dalam perilaku tersebut sebagai bukti sejauh mana efektivitas pelaksanaan coaching kepemimpinan (Ely, et al., 2010).

\section{d. Hasil (Result)}

Kirkpatrick level ke empat mengacu pada dampak coaching terhadap pencapaian tujuan organisasi, meliputi variabel seperti produktivitas, pendapatan, dan hak kepemilikan. Menilai hasil coaching kepemimpinan membutuhkan sebuah perspektif level sistem yang tidak hanya memperhatikan pada hasilnya saja, namun juga pengaruhnya terhadap organisasi secara keseluruhan. Evaluasi juga memperhitungkan pengaruh coaching terhadap bawahan, rekan kerja, dan atasan coachee. Konsisten dengan hal tersebut, Kaiser, Hogan, \& Craig (2008) menyatakan bahwa evaluasi hasil coaching juga akan memerlukan penilaian proses di level bawah seperti motivasi kerja, kepuasan kerja, dan kepuasan terhadap pemimpin, serta penilaian hasil tingkat bawahan seperti produktivitas pekerjaan kelompok atau kualitas keluaran.

Evaluasi sumatif ini memberikan informasi apakah proses coaching telah berjalan dengan baik atau tidak, tahapannya meliputi pengumpulan informasi deskriptif dan penilaian yang diperlukan untuk membuat keputusan tentang manfaat coaching dan mengidentifikasi area-area untuk perubahan dan perbaikan (Goldstein \& Ford, 2002). Meskipun demikian, penggunaan evaluasi sumatif saja untuk menentukan masalah yang akan diperbaiki dan ditingkatkan dalam evaluasi coaching sangat sulit, karena itu evaluasi coaching juga harus mencakup komponen formatif. Tujuan utama dari evaluasi formatif ini adalah untuk meningkatkan kualitas proses coaching yang dilakukan sehingga meningkatkan kemungkinan untuk mencapai tujuan yang diinginkan (Burns, 2014). Evaluasi formatif lebih fokus pada kriteria proses dan akan memberikan informasi untuk dapat memahami dan meningkatkan kualitas coaching (Goldstein \& Ford, 2002). Peneliti harus mendiagnosis karakteristik coach, coachee, dan hubungan di antara keduanya sehingga kegagalan dalam mengidentifikasi permasalahan dalam pencapaian tujuan pembelajaran sebagai akibat sejumlah faktor seperti kurangnya kesiapan klien, keterampilan coach, atau hubungan antara coach dan coachee dapat diketahui. Kerangka evaluasi formatif ini ditunjukkan oleh Tabel 2.

Tabel 2. Kerangka Evaluasi Formatif Coaching

\begin{tabular}{|c|c|c|}
\hline \multicolumn{2}{|r|}{ Fokus Evaluasi } & \multirow{2}{*}{\begin{tabular}{l}
\multicolumn{1}{c}{ Sumber Data Relevan } \\
- Penilaian perilaku dan keahlian (coachee) \\
- Harapan (coachee) \\
- Wakil organisasi
\end{tabular}} \\
\hline Klien: & $\begin{array}{l}\text { - Kesiapan coachee } \\
\text { - Harapan coachee terhadap coaching } \\
\text { - Dukungan organisasi, sasaran, dan iklim }\end{array}$ & \\
\hline Coach: & $\begin{array}{l}\text { - Kesiapan coach } \\
\text { - Kompetensi coaching; } \\
\text { - Keahlian dalam coaching, keterampilan atau bisnis tertentu }\end{array}$ & $\begin{array}{l}\text { - Sertifikasi pengalaman (coach) } \\
\text { - Latar belakang (coach) }\end{array}$ \\
\hline $\begin{array}{l}\text { Hubungan } \\
\text { Klien - } \\
\text { Coach: }\end{array}$ & $\begin{array}{l}\text { - Kemampuan membangun hubungan (building rapport) } \\
\text { - Kolaborasi (misal: tingkat kolaborasi dalam merumuskan tujuan) } \\
\text { - Komitmen (mis.upaya coachee dalam mencapai tujuan) } \\
\text { - Kepercayaan dan kerahasiaan }\end{array}$ & - Laporan coach dan coachee \\
\hline $\begin{array}{l}\text { Proses } \\
\text { Coaching: }\end{array}$ & $\begin{array}{l}\text { - Penilaian (mis. penerimaan coachee terhadap hasil penilaian) } \\
\text { - Tantangan (mis. Jumlah dan kualitas tujuan pengembangan) } \\
\text { - Dukungan (mis. Penyediaan sumber daya untuk fasilitasi } \\
\text { pencapaian sasaran) }\end{array}$ & $\begin{array}{l}\text { - Rencana pengembangan pembelajaran (coach) } \\
\text { - Rencana pengembangan pembelajaran (coach) } \\
\text { - Penilaian dari perilaku coachee }\end{array}$ \\
\hline & & Sumber: Ely (2010) dengan penyesuaian \\
\hline
\end{tabular}


Fokus dalam evaluasi formatif coaching dalam tabel di atas meliputi tiga aspek sebagai berikut:

\section{a. Kesiapan Coach dan Coachee}

Kesiapan coach dan coachee ini mulai dari tahap perencanaan hingga pencapaian tujuan. Hal ini sama dengan penilaian kebutuhan sebelum program pelatihan dimulai untuk menilai faktor kesiapan peserta pelatihan (Goldstein \& Ford, 2002). Tingkat kesiapan, harapan, kompetensi dan keterampilan yang mereka harapkan dari pelatihan berbeda-beda. Seringkali peserta mengikuti pelatihan hanya karena penugasan dari pimpinan, sehingga hasil penilaian kondisi organisasi akan membantu coach untuk memahami tujuan dan iklim organisasi (Ely, et al., 2010). Selain itu, perlu dipertimbangkan faktor-faktor lainnya, termasuk kompetensi coaching (mis. kemampuan komunikasi dan memotivasi) dan pengetahuan serta pemahaman terhadap permasalahan yang akan menjadi topik pembicaraan.

\section{b. Hubungan Coach - Coachee}

Faktor hubungan, kolaborasi, dan komitmen antara coach dan coachee merupakan komponen yang sangat penting (Dingman, 2006; fielden, 2005; Connor dan Pokora, 2007). Penilaian terhadap ketiga faktor tersebut akan memberikan informasi kepada coach tentang bagaimana membangun hubungan yang baik dan mengidentifikasi area potensial yang mungkin dapat menghambat keberhasilan coaching. Faktor tersebut dievaluasi dengan cara menilai hubungan saling pengertian antara coach dan coachee mengenai tujuan coaching, mengukur tingkat kolaborasi dalam merumuskan tujuan pengembangan, dan menganalisis komitmen coachee melalui penilaian terhadap upaya coachee untuk menyelesaikan kegiatan yang direkomendasikan oleh coach. Kepercayaan dan kerahasiaan juga dimasukkan ke dalam penilaian karena akan berakibat terhadap kurangnya dialog yang terbuka dan jujur antara keduanya (Ely, et al., 2010).

\section{c. Proses coaching}

Hasil evaluasi formatif memberikan informasi mengenai aspek apa saja yang dapat memfasilitasi pencapaian tujuan pengembangan coachee, dan coach dapat menggunakan informasi tersebut untuk memandu sesi coaching selanjutnya. Selain itu juga memberikan panduan coach tentang bagaimana menyeimbangkan setiap tahapan proses coaching, di antara komponen penilaian, tantangan, dan dukungan (Dingman, 2006; Velsor, McCauley, \&
Ruderman, 2010; Munro, 2016) serta seberapa penekanan pada masing-masing tahapan tersebut. Coach akan memeriksa perangkat penilaian dan penerimaan coachee terhadap hasil penilaian. Fase tantangan dapat dinilai berdasarkan jumlah dan kualitas capaian berdasarkan tujuan pembelajaran dan penyelarasannya dengan kebutuhan coachee. Sedangkan penilaian dukungan difokuskan pada sumber daya yang diberikan kepada coachee untuk memfasilitasi pencapaian tujuan.

\section{METODE PENELITIAN}

Tulisan ini merupakan kajian terhadap efektivitas pelaksanaan coaching pada pelatihan kepemimpinan yang telah diselenggarakan oleh PPSDM Aparatur selama ini. Pendekatan yang dilakukan, mengacu pada kerangka evaluasi sumatif 4 level Kirkpatrick dan kerangka evaluasi formatif dengan mempertimbangkan semua aspek yang akan berpengaruh terhadap efektivitas proses coaching pada penyelenggaraan pelatihan kepemimpinan. Studi literatur juga dilakukan, merujuk pada penelitian-penelitian yang telah dilakukan sebelumnya, difokuskan pada jurnal, buku, maupun hasil penelitian lain yang relevan dengan topik penelitian.

Persiapan evaluasi coaching dimulai dengan menyeleksi semua kriteria evaluasi yang akan dilakukan (berdasarkan kebutuhan pemangku kepentingan). Langkah selanjutnya adalah mengembangkan sebuah rencana evaluasi yang meliputi, identifikasi sumber data yang relevan dan metodologi untuk pengumpulan data. Pengembangan instrumen evaluasi coaching dilakukan menggunakan kerangka evaluasi sumatif Kirkpatrick (Tabel 1) dan kerangka evaluasi formatif coaching (Tabel 2). Kerangka kerja evaluasi Kirkpatrick ini juga dilengkapi dengan pendekatan multidimensi yang mempertimbangkan semua aspek yang nantinya akan berpengaruh terhadap efektivitas proses coaching yang akan dilakukan. Kerangka kerja evaluasi yang dibangun akan memberikan mekanisme untuk mendapatkan kriteria hasil yang relevan.

Survei dilakukan melalui penyebaran kuesioner kepada para responden yang akan digunakan untuk mengevaluasi sejauh mana efektivitas pelaksanaan coaching pada peserta pelatihan kepemimpinan di PPSDM Aparatur selama ini. Responden dalam penelitian ini berjumlah 37 orang, alumnus Diklatpim IV tahun 2018 (Angkatan 2 dan 3) dan Widyaiswara (Coach).

Skala Likert (Likert Scale) digunakan untuk mengukur sikap dan pendapat para responden yang berisi lima tingkat jawaban mengenai 
kesetujuan responden terhadap statemen atau pernyataan yang dikemukakan melalui opsi jawaban yang disediakan. Pertanyaan-pertanyaan dilakukan secara terbuka dan tertutup (open and closed question) guna memberikan kesempatan kepada para responden apabila memiliki pendapat yang berbeda.

Wawancara terhadap Coach dilakukan untuk memperoleh pemahaman yang lebih dalam tentang hal-hal yang akan mempengaruhi proses coaching dari perspektif mereka. Pertanyaan secara terstruktur akan disusun untuk mengetahui sejumlah faktor seperti kurangnya kesiapan klien, keterampilan coach, atau hubungan antara coach dan coachee akan mempengaruhi pencapaian tujuan pembelajaran melalui metode coaching.

Data hasil kuesioner selanjutnya akan diuji validitas dan reliabilitasnya menggunakan perangkat lunak pengolah data SPSS for Windows. Uji validitas ini dilakukan untuk memastikan valid atau tidaknya variabel penelitian, sedangkan uji reliabilitas digunakan untuk menetapkan apakah instrumen (kuesioner) dapat digunakan lebih dari satu kali, paling tidak oleh responden yang sama untuk menghasilkan data yang konsisten (Sugiyono, 2014). Hasil pengujian validitas diketahui bahwa semua r hitung $>\mathrm{r}$ tabel, menunjukkan bahwa semua atribut (pertanyaan kuesioner) yang diuji adalah valid karena nilai $r$ positif dan lebih besar daripada nilai $r$ tabel $=0,2673$. Sedangkan hasil uji reliabilitas diketahui nilai Cronbach's alpha $>$ 0,7 menunjukkan bahwa $r$ Cronbach's alpha positif dan $>\mathrm{r}$ tabel sehingga atribut yang diuji dianggap reliabel.

Data yang diperoleh dari para responden penelitian selanjutnya akan dianalisis sesuai dengan metode statistik yang digunakan. Hasil pengolahan data diharapkan dapat menggambarkan kejadian, fakta, keadaan, fenomena, atau variabel yang terjadi pada saat penelitian berlangsung yang kemudian akan disimpulkan berdasarkan fakta-fakta tersebut (Sugiyono P. D., 2017). Hasil analisis data kuesioner ini selanjutnya akan ditriangulasikan dengan laporan pascadiklat untuk mengevaluasi sejauh mana tingkat efektivitas program coaching yang telah dilakukan selama ini.

\section{HASIL DAN PEMBAHASAN}

\section{Hasil Pengolahan Data Penelitian}

\section{A. Hasil Evaluasi Coachee}

\section{Evaluasi Level Satu (Reaksi)}

Evaluasi level pertama ini diharapkan menjawab pertanyaan terkait tingkat kepuasan dan manfaat yang dirasakan oleh responden, meliputi:

a. Persepsi coachee terhadap efektivitas coaching;

b. Persepsi coachee terhadap kompetensi dan kapabilitas coach;

Tabel 3. Persepsi Terhadap Efektivitas Coaching

\begin{tabular}{|c|c|c|c|c|c|c|c|c|}
\hline \multirow{2}{*}{ No. } & \multirow{2}{*}{ Pernyataan } & 5 & 4 & 3 & 2 & 1 & \multirow{2}{*}{ Mean } & \multirow{2}{*}{$\begin{array}{c}\text { Std. } \\
\text { Deviasi }\end{array}$} \\
\hline & & $\%$ & $\%$ & $\%$ & $\%$ & $\%$ & & \\
\hline 1. & Coach bersikap sangat bersahabat dan simpatik & 56,8 & 37,8 & 2,7 & 0 & 2,7 & 4,46 & 0,803 \\
\hline 2. & Coach mampu berkomunikasi secara efektif & 54,1 & 35,1 & 5,4 & 5,4 & 0 & 4,38 & 0,828 \\
\hline 3. & Coach mau mendengarkan setiap kesulitan Saya? & 54,1 & 40,5 & 2,7 & 2,7 & 0 & 4,46 & 0,691 \\
\hline 4. & $\begin{array}{l}\text { Coach mampu memberikan umpan balik yang } \\
\text { bermanfaat }\end{array}$ & 56,8 & 35,1 & 2,7 & 5,4 & 0 & 4,43 & 0,801 \\
\hline 5. & $\begin{array}{l}\text { Coach mampu memberikan tantangan terhadap ide/ } \\
\text { gagasan Saya }\end{array}$ & 56,8 & 37,8 & 0 & 5,4 & 0 & 4,46 & 0,767 \\
\hline 6. & $\begin{array}{l}\text { Coach selalu memberi motivasi dan semangat kepada } \\
\text { saya untuk mencapai keberhasilan }\end{array}$ & 70,3 & 27,0 & 0 & 2,7 & 0 & 4,65 & 0,633 \\
\hline 7. & Coach selalu memperhatikan setiap perkembangan Saya & 54,1 & 37,8 & 5,4 & 2,7 & 0 & 4,43 & 0,728 \\
\hline 8. & $\begin{array}{l}\text { Coach telah membantu saya merencanakan Proyek } \\
\text { Perubahan pada setiap tahapan: } \\
\text { a. Mendiagnosis masalah organisasi } \\
\text { b. Berpikir kreatif dan inovatif } \\
\text { c. Pembentukan tim efektif } \\
\text { d. Merancang proyek perubahan }\end{array}$ & $\begin{array}{l}43,2 \\
48,6 \\
40,5 \\
43,2\end{array}$ & $\begin{array}{l}48,6 \\
43,2 \\
43,2 \\
51,4\end{array}$ & $\begin{array}{c}5,4 \\
8,1 \\
10,8 \\
5,4\end{array}$ & $\begin{array}{c}2,7 \\
0 \\
5,4 \\
0\end{array}$ & $\begin{array}{l}0 \\
0 \\
0 \\
0\end{array}$ & $\begin{array}{l}4,32 \\
4,41 \\
4,19 \\
4,38\end{array}$ & $\begin{array}{l}0,709 \\
0,644 \\
0,845 \\
0,594\end{array}$ \\
\hline 9. & $\begin{array}{l}\text { Waktu yang dialokasikan untuk sesi coaching sudah } \\
\text { mencukupi }\end{array}$ & 37,8 & 51,4 & 5,4 & 5,4 & 0 & 4,22 & 0,787 \\
\hline 10. & $\begin{array}{l}\text { Semua sesi Coaching yang dilakukan selamapelatihan } \\
\text { sangat bermanfaat }\end{array}$ & 48,6 & 40,5 & 5,4 & 5,4 & 0 & 4,32 & 0,818 \\
\hline 11. & $\begin{array}{l}\text { Secara keseluruhan saya puas dengan coaching yang } \\
\text { telah dilakukan }\end{array}$ & 51,4 & 37,8 & 5,4 & 5,4 & 0 & 4,35 & 0,824 \\
\hline
\end{tabular}


c. Kepuasan terhadap kualitas hubungan antara coach-coachee; dan

d. Kepuasan terhadap proses pelaksanaan coaching.

Hasil survei yang telah dilakukan menunjukkan bahwa para peserta pada umumnya merasa puas dengan proses coaching yang telah dilakukan. Secara keseluruhan, tingkat kepuasan mereka terhadap pelaksanaan coaching sangat tinggi, mencapai rata-rata 4,35.

\section{Evaluasi Level Dua (Pembelajaran)}

Hasil survei menunjukkan bahwa responden merasakan adanya perubahan tingkat pengetahuan dan keterampilan yang berupa kesadaran baru, fleksibilitas pengetahuan, kemampuan menguasai situasi dan mendapatkan hasil positif (selfefficacy), serta sikap kerja yang baru. Hal ini ditunjukkan oleh nilai rata-rata evaluasi yang mencapai angka 4,31 .

Tabel 4. Persepsi Terhadap Peningkatan Kesadaran dan Pencapaian Pembelajaran

\begin{tabular}{|c|l|c|c|c|c|c|c|c|}
\hline No. & \multicolumn{1}{|c|}{ Pernyataan } & $\mathbf{5}$ & $\mathbf{4}$ & $\mathbf{3}$ & $\mathbf{2}$ & $\mathbf{1}$ & Mean & $\begin{array}{c}\text { Std. } \\
\text { Deviasi }\end{array}$ \\
\hline 1. & $\begin{array}{l}\text { Saya merasa proses coaching telah memberikan } \\
\text { pengalaman positif }\end{array}$ & 48,6 & 43,2 & 5,4 & 2,7 & 0 & 4,38 & 0,721 \\
\hline 2. & $\begin{array}{l}\text { Coaching telah membuka wawasan/ perspektif baru } \\
\text { Saya dalam melihat permasalahan organisasi }\end{array}$ & 45,9 & 43,2 & 5,4 & 5,4 & 0 & 4,30 & 0,812 \\
\hline 3. & $\begin{array}{l}\text { Coaching telah membantu Saya untuk membangun } \\
\text { rencana dan strategi mencapai tujuan (goal setting) } \\
\text { yang ingin dicapai? }\end{array}$ & 48,6 & 37,8 & 8,1 & 5,4 & 0 & 4,30 & 0,845 \\
\hline 4. & $\begin{array}{l}\text { Coaching telah memudahkan Saya untuk mencapai } \\
\text { tujuan yang telah ditetapkan }\end{array}$ & 40,5 & 51,4 & 8,1 & 0 & 0 & 4,32 & 0,626 \\
\hline 5. & $\begin{array}{l}\text { Coaching telah memberikan dampak terhadap } \\
\text { peningkatan kemampuan Saya untuk bekerja lebih } \\
\text { efektif dan efisien }\end{array}$ & 48,6 & 37,8 & 8,1 & 5,4 & 0 & 4,24 & 0,925 \\
\hline 6. & $\begin{array}{l}\text { Coaching telah membuat Saya lebih termotivasi dan } \\
\text { percaya diri untuk mencapai tujuan yang diinginkan }\end{array}$ & 48,6 & 37,8 & 8,1 & 5,4 & 0 & 4,30 & 0,845 \\
\hline
\end{tabular}

\section{Evaluasi Level Tiga (Perilaku)}

Hasil pengukuran sebesar 4,25 menunjukkan bahwa reponden merasakan adanya perubahan dalam perilaku kepemimpinannya, baik pada saat menghadapi permasalahan organisasi, mengelola pekerjaan/perubahan, dan mengelola serta beker- jasama dalam tim. Hal ini juga dikuatkan dari hasil evaluasi pascadiklat yang menyebutkan sebanyak 43 dari 44 responden $(98 \%)$ menyatakan adanya perubahan perilaku kerja ke arah yang lebih baik (EPD, 2018). Mereka juga lebih melibatkan stakeholder dan memiliki target yang jelas (67\%).

Tabel 5. Persepsi Terhadap Perubahan Perilaku dalam Kinerja dan Kepemimpinan

\begin{tabular}{|c|l|c|c|c|c|c|c|c|}
\hline \multirow{2}{*}{ No. } & \multicolumn{1}{|c|}{ Pernyataan } & $\mathbf{5}$ & $\mathbf{4}$ & $\mathbf{3}$ & $\mathbf{2}$ & $\mathbf{1}$ & \multirow{2}{*}{ Mean } & $\begin{array}{c}\text { Std. } \\
\text { Deviasi }\end{array}$ \\
\cline { 3 - 9 } & $\mathbf{\%}$ & $\mathbf{\%}$ & $\mathbf{\%}$ & $\mathbf{\%}$ & $\mathbf{\%}$ & & 0,838 \\
\hline \hline 1. & $\begin{array}{l}\text { Coaching telah mengajarkan bagaimana seharusnya } \\
\text { menghadapi permasalahan organisasi }\end{array}$ & 37,8 & 48,6 & 8,1 & 5,4 & 0 & 4,19 & 0 \\
\hline 2. & $\begin{array}{l}\text { Coaching telah membantu saya memahami bagaimana } \\
\text { mengelola dan bekerjasama dalam tim kerja }\end{array}$ & 45,9 & 43,2 & 5,4 & 5,4 & 0 & 4,30 & 0,812 \\
\hline 3. & $\begin{array}{l}\text { Coaching mampu mengubah cara saya dalam } \\
\text { merencanakan dan mengelola pekerjaan / perubahan }\end{array}$ & 48,6 & 32,4 & 16,2 & 2,7 & 0 & 4,27 & 0,811 \\
\hline
\end{tabular}

\section{Evaluasi Level Empat (Hasil)}

Hasil kuesioner menunjukkan bahwa coaching diakui telah berdampak positif terhadap pengelolaan tugas dan pekerjaan, baik pada saat perencanaan maupun pelaksanaan. Pengukuran dampak coaching terhadap organisasi dan hasil kinerja ini memberikan nilai cukup memuaskan $(4,29)$. Hal ini diperkuat oleh hasil evaluasi pascadiklat yang $86 \%$ alumnusnya (38 orang) menyatakan setuju bahwa kinerja mereka meningkat setelah mengikuti Pelatihan. Wujud peningkatan kinerja ini meliputi, kemampuan berkaloborasi, efektivitas dan efisiensi, visioner, pengambilan keputusan, dan mencapai target/sasaran kinerja. Dampak pelatihan terhadap peningkatan kinerja organisasi ini juga ditunjukkan dari hasil evaluasi pascadiklat dimana 40 orang coachee $(91 \%)$ dan 7 dari 8 mentor (95\%) yang menyatakan bahwa organisasi telah memperoleh banyak manfaat dari proyek perubahan yang telah dilaksanakan. 
Tabel 6. Pengukuran Dampak Terhadap Kinerja Organisasi

\begin{tabular}{|c|l|c|c|c|c|c|c|c|}
\hline No. & \multicolumn{1}{|c|}{ Pernyataan } & $\mathbf{5}$ & $\mathbf{4}$ & $\mathbf{3}$ & $\mathbf{2}$ & $\mathbf{1}$ & \multirow{2}{*}{ Mean } & $\begin{array}{c}\text { Std. } \\
\text { Deviasi }\end{array}$ \\
\hline \hline 1 & $\begin{array}{l}\text { Coaching telah mampu membuka wawasan dan } \\
\text { perspektif baru }\end{array}$ & 48,6 & 35,1 & 10,8 & 5,4 & 0 & 4,27 & 0,871 \\
\hline 2 & $\begin{array}{l}\text { Coaching telah membantu saya bekerja lebih efektif } \\
\text { dalam membuat perencanaan pekerjaan dan } \\
\text { mengelolanya }\end{array}$ & 48,6 & 35,1 & 13,5 & 2,7 & 0 & 4,30 & 0,812 \\
\hline 3 & $\begin{array}{l}\text { Coaching telah mampu meningkatkan kualitas } \\
\text { perencanaan dan pelaksanaan pekerjaan saya }\end{array}$ & 48,6 & 37,8 & 8,1 & 5,4 & 0 & 4,30 & 0,845 \\
\hline
\end{tabular}

\section{B. Hasil Evaluasi Coach}

Kompetensi coaching mutlak harus dimiliki oleh para Widyaiswara yang ditunjuk menjadi coach dalam pelatihan kepemimpinan yang diselenggarakan di PPSDM Aparatur karena akan berpengaruh terhadap keberhasilan para peserta pelatihan dalam pembelajaran. Namun, hasil kuesioner dan wawancara menunjukkan masih terdapat pemahaman dan penerapan yang berbeda terhadap teknik dan proses coaching yang dilakukan dalam pelatihan kepemimpinan tersebut.
Evaluasi formatif coaching ini dilakukan melalui pengukuran terhadap kompetensi coach dan proses coaching yang dilakukan melalui 14 (empat belas) pertanyaan dalam kuesioner yang kemudian dilanjutkan dengan proses wawancara untuk mengetahui secara lebih memahami permasalahan mereka. Hasil survei terhadap coach dalam penyelenggaraan Diklatpim Tingkat IV tahun 2018 di PPSDM Aparatur ditunjukkan oleh Tabel 7 dibawah ini:

Tabel 7.Evaluasi Coach Terhadap Pelaksanaan Coaching

\begin{tabular}{|c|c|c|c|c|c|c|c|c|}
\hline \multirow{2}{*}{ No. } & \multirow{2}{*}{ Pernyataan } & \multicolumn{5}{|c|}{ Frekuensi } & \multirow{2}{*}{ Mean } & \multirow{2}{*}{$\begin{array}{c}\text { Std. } \\
\text { Deviasi }\end{array}$} \\
\hline & & 5 & 4 & 3 & 2 & 1 & & \\
\hline 1. & $\begin{array}{l}\text { Saat melakukan Coaching, Anda memfasilitasi percakapan dengan } \\
\text { menggunakan pertanyaan terbuka (open ended questions) }\end{array}$ & 3 & 2 & 1 & 0 & 0 & 4,33 & 0,816 \\
\hline 2. & Saya selalu melakukan coaching sesuai tahapannya (Coaching Steps) & 1 & 2 & 3 & 0 & 0 & 3,67 & 0,816 \\
\hline 3. & $\begin{array}{l}\text { Anda selalu memberi kesempatan kepada Coachee untuk menyampaikan } \\
\text { berbagai permasalahan dan ide/gagasan sampai pada kesimpulan akhir } \\
\text { dalam kerangka berpikir mereka }\end{array}$ & 3 & 3 & 0 & 0 & 0 & 4,50 & 0,548 \\
\hline 4. & $\begin{array}{l}\text { Pada saat Coaching, Anda hanya akan fokus pada agenda yang telah } \\
\text { Anda ditetapkan }\end{array}$ & 1 & 1 & 2 & 3 & 0 & 3,17 & 1,169 \\
\hline 5. & $\begin{array}{l}\text { Pada saat Coaching, Anda akan mencoba mengarahkan Coachee untuk } \\
\text { melakukan pekerjaan/kegiatan berdasarkan pengalaman Anda }\end{array}$ & 0 & 1 & 1 & 3 & 1 & 2,33 & 1,033 \\
\hline 6. & $\begin{array}{l}\text { Anda melakukan Coaching pada Coachee Anda secara konsisten dan } \\
\text { periodik }\end{array}$ & 1 & 3 & 1 & 0 & 1 & 3,50 & 1,378 \\
\hline 7. & $\begin{array}{l}\text { Pada saat Coaching, apakah Anda mengajukan pertanyaan yang tidak } \\
\text { Anda ketahui jawabannya }\end{array}$ & 1 & 3 & 1 & 1 & 0 & 3,67 & 1,033 \\
\hline 8. & $\begin{array}{l}\text { Anda sering mengalami kesulitan untuk menahan diri menyampaikan } \\
\text { pendapat pribadi dalam sebuah sesi Coaching }\end{array}$ & 0 & 0 & 2 & 3 & 1 & 2,17 & 0,894 \\
\hline 9. & $\begin{array}{l}\text { Dalam sesi Coaching, Anda bertindak sebagai pemecah masalah } \\
\text { (problem solver) bagi para Coachee }\end{array}$ & 0 & 0 & 2 & 2 & 2 & 2,00 & 0,894 \\
\hline 10. & $\begin{array}{l}\text { Anda seringkali kesulitan untuk menemukan topik yang akan dibahas } \\
\text { selama sesi Coaching }\end{array}$ & 0 & 1 & 0 & 3 & 2 & 2,00 & 1,095 \\
\hline 11. & $\begin{array}{l}\text { Anda seringkali mengalami kesulitan untuk membuat Coachee Anda } \\
\text { membuka diri }\end{array}$ & 0 & 1 & 1 & 3 & 1 & 2,33 & 1,033 \\
\hline 12. & $\begin{array}{l}\text { Anda selalu melakukan pengamatan terhadap perilaku Coachee Anda } \\
\text { selama pelatihan agar dapat memberikan umpan balik lebih akurat }\end{array}$ & 0 & 4 & 1 & 0 & 1 & 3,33 & 1,211 \\
\hline 13. & $\begin{array}{l}\text { Setiap peserta pelatihan yang Anda bimbing terbuka untuk melakukan } \\
\text { Coaching kapan saja }\end{array}$ & 2 & 3 & 0 & 1 & 0 & 4,00 & 1,095 \\
\hline 14. & $\begin{array}{l}\text { Pada saat menjadi Coach, Anda merasa sedang menjadi narasumber/ ahli } \\
\text { dalam materi pelajaran yang menjadi topik pembicaraan }\end{array}$ & 0 & 0 & 0 & 4 & 2 & 1,67 & 0,616 \\
\hline
\end{tabular}


Hasil jawaban para coach atas daftar pertanyaan yang diajukan tersebut akan dijelaskan sesuai urutan nomor sebagai berikut:

a. Pada pernyataan pertama tentang pentingnya penggunaan pertanyaan terbuka (open ended questions) dalam proses coaching, sebagian besar coach (5 orang) menyatakan setuju dan satu orang netral. Coach menggunakan teknik mendengarkan secara aktif (active listening techniques) pada saat mengidentifikasi permasalahan dan mencari solusinya, salah satu caranya adalah digunakannya pertanyaan terbuka.

b. Pernyataan nomor dua terkait pelaksanaan coaching sesuai tahapannya; tiga orang coach menyatakan setuju $(50 \%)$ dan tiga lainnya netral $(50 \%)$. Coach yang memilih netral beralasan bahwa proses coaching, terutama pada tahap kontrak kesepakatan dan membangun hubungan serta penilaian awal (assessment) telah dilakukan pada sesi awal coaching pada awal pembelajaran (tahap identifikasi permasalahan) sehingga pada sesi selanjutnya, tidak perlu lagi memulai coaching dari tahap awal. Tahapan coaching dapat langsung difokuskan sesuai dengan capaian tahapan pembelajaran coachee (result orientation). Berdasarkan jawaban tersebut, dapat disimpulkan bahwa sebenarnya para Coach telah melakukan coaching sesuai dengan tahapan yang dipersyaratkan (Dingman, 2006; Kristof-Brown \& Stevens, 2002).

c. Semua coach setuju dengan pernyataan ketiga yang menekankan pentingnya memberikan kesempatan coachee untuk menyampaikan segala permasalahan, ide, gagasan, dan menyimpulkannya dalam kerangka berpikir mereka. Hal ini terkait dengan hubungan kemitraan antara coach dalam proses pemikiran dan proses kreatif yang menginspirasi mereka untuk memaksimalkan potensi pribadi dan profesional mereka (ICF, 2019).

d. Menjawab pertanyaan pentingnya coach untuk fokus pada agenda yang telah ditetapkannya, para coach dalam hal ini masih memiliki jawaban yang beragam yang menunjukkan masih adanya perbedaan pemahaman terhadap teknik dan proses coaching yang dilakukan dalam pelatihan kepemimpinan ini (mean $=$ $3,17)$. Coaching adalah tentang klien sehingga dia yang menetapkan agenda coaching (Connor and pokora, 2007). Sesi coaching berfokus kepada kebutuhan dan masalah coachee untuk mencapai tujuan yang spesifik dan segera (result orientation), bukan hanya agenda coach sendiri.

e. Hasil survei menunjukkan sebagian besar coach tidak setuju dengan pernyataan bahwa coaching bersifat mengarahkan coachee berdasarkan pengalaman mereka. Coaching lebih bersifat membantu coachee untuk mengklarifikasi nilai-nilai, kekuatan diri, dan menentukan prioritas. Coach membantu mengambil pelajaran penting dari pengalaman yang dimiliki oleh coachee (Velsor, McCauley, \& Ruderman, 2010). Coach menggunakan keterampilan dan teknik yang dimilikinya untuk mendukung pembelajaran dan pengembangan potensi para peserta kepemimpinan (Connor and pokora, 2007).

f. Coaching adalah proses yang berkelanjutan antara coach dan coachee, sehingga harus dilakukan secara teratur, terstruktur, dalam proses pemikiran dan proses kreatif yang akan menginspirasi mereka untuk memaksimalkan potensi pribadi dan profesionalismenya (ICF, 2019). Menjawab pertanyaan ini, empat coach menyatakan setuju, dua lainnya netral dan sangat tidak setuju.

g. Pada saat Coach ditanya apakah akan mengajukan pertanyaan-pertanyaan yang mereka sendiri tidak mengetahui jawabannya, empat orang coach menyatakan setuju dan dua lainnya netral serta kurang setuju. Pada saat diwawancarai, keempat coach tersebut menyatakan bahwa mereka memang harus selalu pada posisi netral sehingga dapat mengajukan pertanyaan-pertanyaan yang mengeksplorasi tanpa mengarahkan coachee untuk melakukan tindakan tertentu. Dalam hal ini sebagian besar Coach sudah memahaminya, meskipun masih ada yang belum dapat menerapkan sepenuhnya.

h. Dalam sesi coaching, empat orang coach menyatakan mampu menahan diri untuk tidak menyampaikan pendapat pribadinya, sedang dua lagi menyatakan netral. Perlu ditegaskan bahwa peran coach adalah membantu pembelajaran dan pengembangan coachee melalui keterampilan dan teknik yang dimilikinya sehingga tidak boleh terjebak ke dalam mentoring.

i. Pertanyaan kesembilan memiliki kemiripan dengan pernyataan lima, empat orang responden menyatakan ketidaksetujuannya apabila bertindak sebagai pemecah masalah, sedangkan dua orang lagi memilih netral.

j. Coaching adalah tentang coachee, sehingga topik atau agenda setiap sesinya ditetapkan 
oleh coachee sesuai kebutuhannya. Coaching merupakan salah satu metode pembimbingan yang dilakukan untuk memfasilitasi pembelajaran selain mentoring, maka kesiapan coach dan coachee sangat diperlukan karena harus disesuaikan dengan tujuan dan hasil (output) dari setiap agenda pembelajaran itu sendiri. Pelaksanaan coaching pada akhirnya akan berjalan sesuai dengan perkembangan pembelajaran sehingga dapat dikatakan bahwa antara coaching dengan pembelajaran dapat terintegrasi.

k. Pernyataan terkait kesulitan coach untuk membuat coachee-nya membuka diri selama sesi coaching, empat orang menyatakan tidak setuju dan dua sisanya setuju serta netral. Hal ini menunjukkan coach telah memiliki kemampuan dalam membangun hubungan saling percaya dan menghormati.

1. Coach harus memantau dan mengevaluasi kinerja dari coachee-nya sehingga mampu memberikan umpan balik yang akan memberikan informasi tentang strategi dan perencanaan yang efektif sehingga mampu mencapai tujuan yang diinginkan. Namun, hasil survei menunjukkan masih terdapat dua orang coach yang menjawab netral dan tidak setuju.

m. Coach diharapkan membuat kesepakatan kontrak dan sesi coaching dengan coachee, termasuk menjalin komunikasi secara efektif untuk membantu menyelesaikan permasalahannya. Coach harus menyediakan waktu saat dibutuhkan oleh coachee. Coaching dapat dilakukan secara langsung (face to face dan coaching group) maupun secara informal menggunakan media komunikasi, baik telpon, email, dan media sosial.

n. Pertanyaan ini terkait dengan pertanyaan nomor 3, 5, dan 9 menunjukkan peran coach yang tidak untuk mengarahkan, tetapi untuk membantu coachee memaksimalkan potensi pribadi dan profesional mereka (ICF, 2009). Dalam hal ini para Coach memiliki pendapat yang sama.

\section{PENUTUP}

\section{A. Simpulan}

Dari hasil pembahasan di atas dapat disimpulkan sebagai berikut.

1. Hasil evaluasi terhadap pelaksanaan coaching pada pelatihan kepemimpinan menunjukkan hasil sebagai berikut:

a. Level Satu (Reaksi): menunjukkan bahwa para peserta umumnya merasa puas dengan proses coaching yang telah dilaksanakan selama ini (rata-rata 4,35).

b. Level Dua (Pembelajaran): peserta merasakan adanya perubahan tingkat kesadaran dan pencapaian keterampilan yang ditunjukkan oleh nilai rata-rata yang mencapai 4,31 .

c. level Tiga (Perilaku): Hasil evaluasi menunjukkan nilai rata-rata 4,25 artinya para responden merasakan adanya perubahan perilaku kerja dan perilaku kepemimpinan ke arah yang lebih baik. Hal ini juga ditunjukkan oleh hasil evaluasi pascadiklat bahwa dalam melaksanakan pekerjaannya, mereka lebih melibatkan stakeholder dan memiliki target yang jelas (67\%).

d. Level Empat (Hasil): coaching telah memberikan dampak positif terhadap pengelolaan tugas dan pekerjaan mereka yang dibuktikan dari nilai rata-rata survei $(4,29)$. Hal ini sejalan dengan hasil evaluasi pascadiklat yang $86 \%$ alumninya (38 orang) menyatakan bahwa kinerja mereka meningkat setelah mengikuti pelatihan.

2. Hasil evaluasi terhadap coach menunjukkan bahwa Widyaiswara yang telah ditunjuk sebagai coach telah memenuhi persyaratan, yaitu memiliki sertifikat ToT, tersertifikasi sebagai coach, dan telah memiliki pengalaman mengajar pelatihan kepemimpinan serta memiliki hasil penilaian sikap dan perilaku yang baik.

3. Hasil survei menunjukkan masih terdapat perbedaan persepsi, terutama dalam penerapan teknik dan proses coaching sehingga dikhawatirkan akan berpengaruh terhadap efektivitas dari sesi coaching yang dilakukan.

\section{B. Saran}

Berdasarkan hasil penelitian ini maka saransaran yang dapat diberikan untuk pengevaluasian coaching ke depannya adalah sebagai berikut.

1. Model dan aplikasi kerangka kerja Kirkpatrick untuk mengevaluasi pelaksanaan coaching perlu terus dikembangkan dengan mempertimbangkan semua aspek yang akan berpengaruh terhadap efektivitas pelaksanaannya (pendekatan multidimensi) sehingga akan memberikan hasil evaluasi yang relevan;

2. Penilaian terhadap perubahan perilaku atau kompetensi kepemimpinan peserta pelatihan sebaiknya dilakukan melalui penilaian $360^{\circ}$, baik dari atasan, rekan kerja, bawahan maupun pemangku kepentingan terkait lainnya.

3. Perlu penyamaan persepsi dari semua pihak terhadap penerapan teknik dan proses coaching 
dalam pelatihan kepemimpinan yang diselenggarakan di PPSDM Aparatur sehingga efektivitasnya dapat ditingkatkan.

\section{DAFTAR PUSTAKA}

Andrea D. Ellinger, A. S. (2003). Supervisory Coaching Behavior, Employee Satisfaction, and Warehouse Employee Performance: A Dyadic Perspective in the Distribution Industry. Human Resource Development Quarterly, 14, 435-458.

Annette Fillery, T. D. (April 2006). Does coaching work or are we asking the wrong question? International Coaching Psychology, 1(No. 1), 24-36.

Baldwin, T. T., \& Ford, J. (1988). Transfer of Training: A Review and Directions for Future Research. Personnel Psychology, 63-105.

Bates, R. (2004). A Critical Analysis of Evaluation Practice: the Kirkpatrick Model and the Principle of Beneficence. Evaluation and Program Planning, 341-347.

Bozer, G., \& Joo, B. K. (2015). The Effects of Coachee Characteristics and Coaching Relationships on Feedback Receptivity and Self-Awareness in Executive Coaching. International Leadership Journal, 36-57.

Bandura, A. (1991). Social Cognitive Theory of Self-Regulation. Elsevier Inc., 248-287

Biggs, J., \& Tang, C. (2007). Teaching for Quality Learning at University. New York: McGrawHill, The Society for Research into Higher Education

Blackman, A. C. (2007). The Effectiveness of Business Coaching: An Empirical Analysis of The Factor That Contribute to Succesful Outcomes. North Queensland: James Cook University

Blackman, A. (2010, September). Coaching as a Leadership Development Tool for Teachers. International Professional Development in Education, 36, 421-441.

Brian O. Underhill , K. J. (June 2008). Executive Coaching for Results: The Definitive Guide to Developing Organizational Leaders (1st ed., Vol. 45). San Francisco: Berrett-Koehler Publishers, Inc.

Burns, M. K. (2014). What is Formative $\begin{array}{lllllllllll}E & v & a & l & u & a & t & i & o & n\end{array}$ https://www.researchgate.net/publication/ $239588953,1-7$.

Campone, F. (2015). Executive Coaching Practices in the Adult Workplace. Wiley Periodicals, Inc. doi:10.1002/ace.20152

Carver, C. S., \& Scheier, M. F. (1998). On the Self-
Regulation of Behavior. Cambridge, UK: Cambridge University Press

Connor M. and Pokora J. (2007). Coaching and Mentoring at Work, Developing effective practice, McGraw Hill, England

Dingman, M. E. (2006). Executive Coaching: Whats the Big Deal? International Journal of Leadership Studies, Vol. 1 Iss. 2, 2006, 2-5

Ely, K., Boyce, L., Nelson, J., Zaccaro, S., Brome, G., \& Whyman, W. (2010). Evaluating Leadership Coaching: A Review and Integrated Framework. US: Institute For Information Technology Applications US Air ForceAcademy

Feldman, D. C., \& Lankau, M. J. (2005). Executive Coaching: A Review and Agenda for Future Research. Journal of Management, 829-848.

Federation, I. C. (1998). Client Survey Results and Press Release: Analysis of the 1998 Survey coaching clients by the International Coach Federation. Retrieved February 1, 2019 from http://www.coachfederation.org.

Fielden, S. (2005). Literature review: coaching effectiveness a summary. Retrieved from http://literacy.kent.edu/coaching/information/ Research/NHS_CDWPCoachingEffectiveness .pdf

Forum, T. E. (2015). The Executive Coaching Handbook: Principles and Guidelines for a Successful Coaching Partnership. Boston: The Executive Coaching Forum

Francis A. Kombarakaran, J. M., \& Pauline B. Fernandes. (2008). Executive Coaching: It Works! Consulting Psychology Journal: Practice and research, 60(No. 1), 78-90.

Goldstein, I. L., \& Ford, J. K. (2002). Training in Organizations: Needs Assessment, Development, and Evaluation. Belmont, CA 94002-2098 USA: Wadsworth-Thoms on Learning

Grosseck, M.-D. (2014). Teaching, coaching, training crosswords for someone, keywords in higher education for others. Procedia-Social and Behavioural Sciences, 1243-1247. doi:10.1016/j.sbspro.2014.01.376

Grover, S., \& Furnham, A. (2016). Coaching as a Developmental Intervention in Organisations: A Systematic Review of Its Effectiveness and the Mechanisms Underlying It. Plos One, 2

International Coach Federation . (2019, February 13). A Chartered Chapter of the International Coach Federation (ICF). Retrieved from International Coach Federation (ICF): https://icfwashingtonstate.com 
Joyce E. Bono, R. A., \& David B. Peterson. (2009). A Survey of Executive Coaching Practices. Personnel Psychology, 361-404

Kaiser, R. B., Hogan, R., \& Craig, S. B. (2008). Leadership and the Fate of Organizations. The American Psychological Association, 96-110

Killburg, R. R. (1996). Toward a conceptual understanding and definition of executive coaching. Washington DC: Consulting Psychology Journal: Practice and Research.

Kirkpatrick, D. L., \& Kirkpatrick, J. D. (1998). Evaluating Training Program The Four Levels. San Francisco: Berret-Koehler Publisher Inc.

Kirkpatrick, J., \& Kirkpatrick, W. K. (2014). Implement the Four Levels of Evaluation to Demonstrate Value. In A. S. Development, ASTD Handbook: The Definitive Reference for Training \& Development (pp. 471-487). Alexandria, VA 22313-1443 USA: American Society for Training \& Development (ASTD)

Koonce, R. (2010). Executive coaching: Leadership development in the federal government. Public Manager, 44-51

Kristof-Brown, A., \& Stevens, C. K. (2002). Goal Congruence in Project Teams: Does the Fit Between Members' Personal Mastery and Performance Goals Matter? Journal of Applied Psychology, 86(6):1083-1095

Kreiger, K., \& Ford, J. K. (1993). Application of Cognitive, Skill-Based, and Affective Theories of Learning Outcomes to New Methods of Training Evaluation. Jurnal of Applied Phychology Monograph, 311-328.

MacKie, D. (2007). Evaluating the Effectiveness of Executive Coaching: Where Are We Now and Where Do We Need To Be? Brisbane, Queensland, Australia: The Australian Psych. Society.

Mackenzie, H. (2007). Stepping off the treadmill: a study of coaching on the RCN Clinical Leadership Programme. International Journal of Evidence Based Coaching and Mentoring, 22.

Mark L. Dean, Ph.D., A. (2002). Executive Coaching: In Search of a Model. Journal of Leadership Education, 1-15.

Mary Devine, R. C. (2013). How Can Coaching Make a Positive Impact Within Educational Settings? Procedia-Social and Behavioral Sciences, 1382-1389

McCauley, C., \& Hughes-James, M. (1994). An Evaluation of the Outcomes of a Leadership Development Program. Center for Creative Leadership. North Carolina
Milena Schalk, J. (2017). Internal versus external executive coaching. An International Journal of Theory, Research and Practice, 1-17

McDermott, M., \& Levenson, A. (2007). What Coaching Can and Cannot Do For Your Organization. Human Resource Planning, 3037

Munro, C. (2016, August 27). Coaching in education: an introduction. e-Leading: Management Strategies for School Leaders, p. 1.

M. Nyman, L. (2002). Coaching as a new leadership development option. Supervision, 36.

ODell, J. (2011). An Evaluation of Coaching Effectiveness from a Psychological Perspective. A Thesis. Faculty of Humanities

Pfeiffer. (2005). Best Practices in Leadership Development and Organization Change: How the Best Companies Ensure Meaningful Change and Sustainable Leadership. San Francisco: John Wiley \& Sons

PPSDM Aparatur. (2018). Laporan Evaluasi Pascadiklat Dikpim Tingkat IV. Bandung: Sub bidang Evaluasi Diklat

Ritu Agarwal, M. C. (2009, October). The performance effects of coaching: a multilevel analysis using hierarchical linear modeling. The International Journal of Human Resource Management, 20, 2110-2134.

Salas, J.A.B., Tannenbaum, S., \& Mathieu, J. (1995). Toward Theoretically Based Principles of Training Effectiveness: A Model and Initial Empirical Investigation. Military Psych., 141-164.

Schmidt, R. A., \& Bjork, R. A. (1992). New Conceptualizations of practice: Common Priciples in Three Paradigms Suggest New Concept for Training. Psychological Science, 207-217

Sugiyono. (2014). Metode Penelitian Kuantitatif, Kualitatif, dan Kombinasi (Mixed Methods). Bandung: Alfabeta

Ting, S., \& Scisco, P. (2006). The CCL Handbook of Coaching: A Guide for the Leader Coach. San Francisco: Jossey-Bass, A Wiley Imprint $\&$ The Center for Creative Leadership.

Velsor, E. V., McCauley, C. D., \& Ruderman, M. N. (2010). The Center for Creative Leadership: Handbook of Leadership Development. San Francisco: Jossey-Bass, A Wiley Imprint.

White, D. (2010). Executive Leadership Coaching. In R. Doug Leigh (Ed.). Silver Spring, Maryland 20910 USA: International 
Society for Performance Development.

Yuki, G. (2012). Effective Leadership Behavior: What We Know and What Questions Need. Academy of Management Executive, 66-85.

Zaccaro, S. J. (1996). Models and Theories of Ex e cutive Le adership: A Conceptual/Empirical Review and Integration. U.S. Army Research Institute for the Behavioral and Social Sciences.

Ke putusan Ke pala LAN Nomor 1008/K.1/PDP.07/2019 tentang Kurikulum
Pelatihan Kepemimpinan Administrator (PKA)

Keputusan Kepala LAN 1006/K.1/PDP.07/2019 tentang Kurikulum Pelatihan Kepemimpinan Pengawas (PKP)

Keputusan Kepala LAN Nomor 1007 K.1 PDP 072019 tentang Pedoman Penyelenggaraan Pelatihan Kepemimpinan Administrator (PKA)

Keputusan Kepala LAN 1005 K.1 PDP.07 2019 tentang Pedoman Penyelenggaraan Pelatihan Kepemimpinan Pengawas (PKP) 